\title{
Children Evidence under the Nigerian Law: The New Approach after the Evidence Act, 2011
}

\author{
Olarinde E. Smaranda1 ${ }^{1}$ Udosen Jacob ${ }^{2}$ \\ ${ }^{1}$ Afe Babalola University, Ado Ekiti, Nigeria \\ ${ }^{2}$ Department of Private and Business Law, College of Law, Afe Babalola University, Ado Ekiti, Nigeria \\ Email: esolarinde@abuad.edu.ng, idemudosen@abuad.edu.ng
}

How to cite this paper: Smaranda, O. E., \& Jacob, U. (2019). Children Evidence under the Nigerian Law: The New Approach after the Evidence Act, 2011. Beijing Law Review, 10, 1394-1408. https://doi.org/10.4236/blr.2019.105075

Received: November 4, 2019

Accepted: December 23, 2019

Published: December 26, 2019

Copyright (c) 2019 by author(s) and Scientific Research Publishing Inc. This work is licensed under the Creative Commons Attribution International License (CC BY 4.0).

http://creativecommons.org/licenses/by/4.0/ cc) (i) Open Access

\begin{abstract}
In our adversarial system, parties are required to tender material evidence to establish the facts-in-issue upon which their claims, charges or defences are based. By giving evidence linking to the claim, charge or defence, the witness performs a duty of assisting the court to discover the truth of the matter. Generally, a competent witness may be adult, children or an old person. The thrust of this paper is to examine child evidence under the Evidence Act, 2011. The author adopted expository, analytical and comparative methods in conducting this research. The study found that under the Evidence Act, 2011, a child of fourteen years is permitted to give sworn evidence while children below fourteen years give unsworn evidence. The paper suggests that Section 209 (3) of the Evidence Act be amended to read "a child's evidence in criminal proceedings shall be given unsworn, and such unsworn evidence may be taken as if that evidence had been given on oath", as it is presently the practice in England and Wales.
\end{abstract}

\section{Keywords}

Court Trials, Children Witness, Admissible Evidence, Unsworn Evidence, Corroboration

\section{Introduction}

Witnesses, through ages, have been key prayers in the pursuit of justice. Therefore, fundamentals of Justice necessitate the fact that the truth of any matter must be established on the basis of credible evidence tendered by the parties before the court. This brings the role of a witness as an important constituent of the administration of justice by giving evidence to prove or disprove the facts that give rise to the subject matter of dispute between parties. A witness is one of 
the most important sources of information in discovering the truth about the case, but the pains and troubles he has to undergo to help the Court are as well.

Through witness testimony, the court gets to the bottom of the matter by knowing the truth before exercising its discretion to give a correct judgement in accordance with the defense of justice. The sanctity of the statements made by the witness is considered to be inherent or intact as such statements are made under oath, and the witness is considered present when the incident occurred. Hence, the role of a witness has been of paramount importance in assisting the court to discover the truth in the administration of justice. It is interesting to note that winning or losing a case is dependent on the witness if the case is free from any influence. It must be understood that evidence of a witness will only be admissible if that witness is competent to testify. However, it may happen that the crucial evidence to be relied upon for just determination of a case is that of a child (Amusa, 2014). With the increasing concern about the incidence of sexual abuse of children (where the child is often the sole witness as well as the victim), and about domestic violence (where a child is likely to be a principal witness), the status accorded to children's evidence in our adversary judicial system is coming under closer scrutiny (Thomson, 1958). The status of children's evidence is of crucial significance in our justice system. Therefore, to exclude children's evidence may mean, in cases where the only witness is a child or children, that an offender will not be prosecuted, because there is little or no other credible evidence available against the accused. This means that many criminal acts can be committed with impunity and that children are victims of repeated criminal acts. If, however, a child's evidence is inherently unreliable or a Judge or a Magistrate is unable to assess the reliability of the evidence accurately, then the admission of such evidence may well prejudice the outcome of the trial. It is this concept of child evidence under the Evidence Act, 2011 that this article is set to examine.

\section{Clarification of Terms}

It is to be noted that the Evidence Act is silent on who a child is (Cap E 14, LFN, 2004). This obvious lacuna may make us resort to the various foreign and local legislations in order to ascertain the status of a child. In constitutional law, the age of franchise in Nigeria is eighteen years (Section 77 (2) and 117 (2) CFRN, 1999 (as amended). In contract, the contractual capacity is the age of majority. Under Common Law, the age of puberty differs. A child is one who has not attained the age of fourteen in the case of a boy, while the age of puberty for a girl is twelve years (http://www.yourdictionary.com/puberty). The Oxford Advanced Dictionary defines a child as a person, boy or girl right from birth to the age of full physical development (Hornby, 2004), while The Black's Law Dictionary defines a child as a person under the age of majority (Garner, 2001). The Labour Act defines a child as a young person under the age of twelve years and a young person as one under the age of fourteen years (Garner, 2001). The National 
Welfare Policy defines a child as anybody who is twelve years of age and below. The Children and Young People Act define a child as a person who is under twelve years old; however a young person according to the same Act means a person who is twelve years or older, but not yet an adult. This Act also establishes the difference between a child and a young adult, stating that a child is any person less than twelve years old, while a young person is any person that is twelve years and above, although not yet an adult.

The Child's Right Act 2003 defines a child as a person who has not attained the age of eighteen years which is in line with the United Nations Convention on the Rights of the Child and the African Charter on the Rights and Welfare of the Child of which Nigeria is a State Party (Cap 50, LFN, 2004). Section 277 of the United Nation's Convention on the Rights of the Child establishes that a child is a person below the age of eighteen years.

It is importance to note that the legislation on issues relating to children in Nigeria is contained in the residuary legislative list and as such, depends on the states (Iguh, 2011). Individual states are meant to adopt and adapt to the Child Rights Act. Most states of the Federation like Abia, Anambra, Bayelsa, Ebonyi, Ekiti, Jigawa, Edo, Imo, Lagos, Kwara, Ogun, Ondo, Rivers, Taraba, Nasarawa (Iguh, 2011) have adopted the Child Rights Act and are in the process of adapting the laws accordingly; some states have changed the definition of a child. In some states, a child is a young person under the age of thirteen (Iguh, 2011). In other states like Akwa Ibom, he/she is a young person under the age of sixteen years.

The Criminal Procedure Act, for example, regards any person below the age of fourteen years as a child. In explaining what the age of a child is, the court in the case of Okoye $v$ The State stated inter alias, that: a boy or girl of thirteen years is a child. In similar vein, in the case of State $v$ Njokwa Obia, the court held that: a witness aged fifteen years is not a child. Another case worth mentioning on this issue is the Supreme Court landmark case of Okon $v$ The State where His Lordship Nnaemeka-Agu J.S.C. (as he then was) stated that any person below the age of fourteen years should be regarded as a child. The court went further to state that:

in the absence of any general provision in either the Law (Miscellaneous Provision) Act Cap 89 of 1958, and the interpretation Act of 1964 or any definition of the Evidence Act (Cap 62) itself, I believe in the principles that I have discussed I should adopt and apply the definition in section 2(1) of the Criminal Procedure Act. An Act designed to make provision for the procedure to be allowed in criminal cases under the Act, "child" means anyone who has not attained the age of fourteen years (Dubai Bank Kenya Ltd. V Insurance Company of East Africa Ltd 2004

http://kenyalaw.org/caselaw/cases/view/91860/)

Subsequent decisions also endorse the above namely that a person below the age of fourteen years is a child. On this note, it is the opinions of the writers that 
the perception of age as a definition of a child in Nigeria varies and is also dependent on the person who is defining and his/her cultural background.

\section{Competency and Compellability}

It must be understood from the onset that the evidential concepts of competency and compellability have a universal feature of modern legal systems. Related literature on the competent of a witness to testify in court, in general, and comparability in particular, is most challenging, thoughtful and insightful and at the centre of scholarly discussions in the legal system of many countries including Nigeria. This ranges from writings by scholars and eminent jurist to the case laws. Despite the fact that much has been written on the subject, the debate on the appropriateness of assessing the competency of child witnesses is far from being over. For instance, in England by the $19^{\text {th }}$ century new rules of evidence on the competence of all persons to testify as witnesses had emerged. Thus, in the case of EX P Femande His Lordship Wiles J. (as he then was) succinctly stated the rule thus:

Every person in the United Kingdom except the sovereign may be called upon and is bound to give evidence to the best of his knowledge upon any question of fact material and relevant to an issue in any of the Queen's courts unless he can show some exceptions in his favour.

The above English court's decision finds written expression in Section 175(1) of the Nigerian Evidence Act, which provides:

All persons shall be competent to testify unless the court considers that they are prevented from understanding questions put to them or from giving rational answers to those questions by reason of tender years, extreme old age, disease whether of body or mind or any other cause of the same kind.

By virtue of the above provision, it is clear that a competent person, therefore, maybe described as a person who can lawfully be called upon to give evidence. $\mathrm{He}$ is a person who suffers no disability on account of the law or is not exempted by the provisions of the law from giving evidence (Amusa, 2014).

A compellable witness is a person who can lawfully be compelled by the court to testify (Amusa, 2014). The refusal or neglect on the part of a compellable witness to attend court when summoned may amount to contempt, for which he may be punished. It is noteworthy that a person must be competent before being compellable; in other words, all compellable persons are competent. A competent person may, however not be compellable if the person falls within the class of persons who enjoy privilege or immunity from civil or criminal proceedings.

It flows from the above that a child is reputably presumed incompetent and uncompellable to act as a witness in court (Amusa, 2014). But generally, this presumption can be rebutted if the child is able to overcome the legal hurdles of passing preliminary tests to be conducted by the court to determine his competence (Amusa, 2014). The first test is to investigate whether the child is possessed 
of sufficient intelligence to be able to understand the questions put to him or answer such questions rationally (Amusa, 2014). This can be ascertained by putting questions which have no bearing on the matter in court across to the child. If he scales this hurdle, he is prima facie a competent witness. The second test as earlier stated is for the court to determine if he understands the nature of an oath against the backdrop of speaking the truth. If he passes the second test, the child will be placed on oath and his evidence will be on par with that of an adult (Amusa, 2014). But where he fails the second test but passed the first test, he is nevertheless a competent witness who will be allowed to give unsworn testimony. In Mbele v. The State, Nnaemeka-Agu (JSC) stated the position as follows:

It is thus clear that a judge faced with the testimony of a child witness has two vital investigations to make, namely:

1) Is he or she possessed of sufficient intelligence to justify the retention of his or her evidence, that is, does he or she understand the duty of speaking the truth?

2) Does he understand the nature of an oath?

It is only after the above questions have been answered that an oath can be lawfully administered to the child.

The issue of whether the above stated two basic tests should be conducted in open court before the reception of evidence of a child is contentions. While the case of Omosivbe v.COP support the view that the investigation must first be made in court to justify the child's evidence on record, the cases of Okoye v. The State and Okoyomyo v. The State stated that the trial judge is not bound under Section 183 (1) of the Evidence Act, 2004 to hold and record a preliminary inquiry on the competence of a child to take an oath, if the court is of the opinion that the child is capable of understanding the nature of an oath.

However it has been argued that competency of a child relies more on the understanding and intellect of the child rather than the age of the child. In Onyebu $v$ The State, the Supreme Court held interalia that: "Competency is not a matter of age but understanding ..." In that case, one of the questions that arose for determination was whether Prosecution Witness 5 (PW5), a fourteen-year-old boy who witnessed the gruesome murder of his mother on the farm for declining sexual advances made to her by the Appellant was a competent witness. In the circumstances of the case, he was held to be competent. Also, in Solola $v$ State, the Supreme Court held that competency to testify is not a matter of age but of intellectual capacity. In 1895, the United States Supreme Court, cited the English common law precedent in Wheeler $v$ United States and established the American Common Law Position that the competency of a child witness "depends on the capacity and intelligence of the child, his appreciation of the difference between the truth and falsehood, as well as his duty to tell the former in making such a determination, Judges assessed whether children understood the spiritual consequences" of lying on oath. In 1861 in the English de- 
cision in $R v$. Holmes, the Judge was satisfied that a child had the capacity to give sworn evidence when, after being asked what becomes of a person who tells lies (under oath), the child responded if he tells lies he will go to the wicked fire of hell. The common law perception that children were, not sufficiently trustworthy to serve as witnesses, was a reflection of widespread contemporary beliefs that children could easily be influenced by an adult, especially girls, were inherently unreliable witnesses and prone to fantasy or fabrication, and that crimes such as sexual abuse of children were a rare occurrence.

\section{Evidence of Children: The New Approach after Evidence Act, 2011}

With regard to the competence of a child witness, Section 155 of the Evidence Act, 2004 which is in pari materia with the new Section 175 of the Evidence Act, 2011 which deals with the first test of a child who may be competent to testify in court has brought about some innovations regarding the admissibility of unsworn evidence of a child and the requirement of corroboration. Section 183 of the Evidence Act 2004 provided for the admissibility of unsworn evidence of a child witness in criminal proceedings. Section 209 of the Evidence Act 2011 brought about substantial innovations by not limiting it to criminal proceedings but also civil proceedings. Section 209 provides thus:

In any proceeding in which a child who has not attained the age of fourteen years is tendered as a witness, such child shall not be sworn and shall give evidence otherwise than on oath or affirmation, if in the opinion of the court, he is possessed of sufficient intelligence to justify the reception of his evidence and understands the duty of speaking the truth (Onyekachi, 2016). 209 (2): A child who has attained the age of fourteen years shall, subject to Sections 175 and 208 of the Act give sworn evidence in all cases.

Directly comparing Section 183 of the Evidence Act 2004 and Section 209 of the Evidence Act 2011, it is evident that the former dealt with the unsworn evidence of a child in criminal cases, the latter distinguishes between the competence of a child below the age of fourteen years and that of a child who has attained the age of fourteen years in both civil and criminal proceedings. This is a sharp distinction between the two Evidence Acts. While Section 183 was restricted to criminal cases, Section 209 (1) applies to both civil and criminal cases. Flowing from this, one can say without contradictions that the 2011 Evidence Act is a marked improvement of the previous law.

The new law has established that a child who has not attained the age of fourteen years is not competent to give sworn evidence, unlike its 2004 counterpart. By this section, it is also clear that if a child is below fourteen years of age his evidence shall be unsworn provided he is possessed of sufficient intelligence to justify the reception of his evidence and he understands the duty of speaking the truth unlike former Section 183 of the Evidence Act 2004 which failed to state the age range of who is a child; as such, a definition was sought in other laws, 
and only applied to criminal proceedings. The 2004 Act only applied strictly in civil proceedings to the effect that a child witness, either or below the age of fourteen years, must understand the questions put to him, giving rational answers to those questions, and understands the nature of an oath. The criticism of this provision under the 2004 Act emanated from the question whether a child who is statutorily disqualified from giving evidence on oath will be required to "possess of sufficient intelligence to justify the reception of his evidence and understand the duty of speaking the truth". This phrase is still rearing its ugly head under the 2011 Act.

Also, Section 209 of the 2011 Act has resolved the conflict between the Child Right Act 2003 and the Evidence Act 2004. The Child Rights Act provides:

1) In any proceedings, whether civil or criminal, the evidence of a child may be given unsworn.

2) A deposition of a child's sworn evidence shall be taken for the purpose of any proceedings, whether civil or criminal as if that evidence has been given on oath.

It can be submitted that while the foregoing provisions conflicted with Section 183 (1) of the 2004 Act, which restricted the admissibility of unsworn evidence of a child to criminal proceedings, the conflict has now been resolved by the use of the words; "in any proceedings" in Section 209 (1) of the 2011 Act, thereby allowing the unsworn evidence of a child in civil proceeding.

However, Section 209 (2) makes it explicit that a child who has attained the age of fourteen years shall give sworn evidence in both civil and criminal proceedings. This provision is made subject to the provisions of Section 175 and 208 of the same Act. This means:

1) Even for a child, who has attained the age of fourteen years to give sworn evidence, he must understand the questions put to him or give rational answers to those questions and also understand the nature of an oath.

2) The court may discard with the requirement of administering evidence on oath if it is of the opinion that taking of any oath whatsoever according to the religious belief of the child witness is unlawful or because of lack of religious belief, the court is of the opinion that the child witness ought not to give evidence upon oath.

There was no similar provision under the 2004 Act. It is an exceptional trend brought by the 2011 Act.

Notably, in spite of these improvements, these changes do not go far enough to improve children competency, as Section 209 (3) of the 2011 Act requires that the unsworn evidence of a child below the age of 13years must be corroborated by some other material evidence in support of such testimony:

209 (3): A person shall not be liable to be convicted for an offence unless the testimony admitted by virtue of subsection (1) of this section and given on behalf of the prosecution is corroborated by some other material evidence in support of such testimony implicating the defendant. 
The legal consequences of these provisions are that under Section 209 of the 2011 Act, nothing establishes the provision that even in criminal cases, the unsworn evidence of a child who has attained the age of fourteen years requires corroborative evidence implicating the accused person. On the contrary, the 2004 counterpart established that the unsworn evidence of a child of whatsoever age required corroborative evidence in criminal proceedings, implicating the accused person. This trend in the 2011 Act seems like the incorporation of the views of some Nigerian scholars. For example, Professor Amupitan was of the opinion that:

In order to remove the controversy created by the need for preliminary inquiry or not, a person of fourteen years and above should be treated like an adult who could give sworn evidence in the court while a person below the age of fourteen years should be considered as a child whose evidence requires special treatment, although the new Evidence Act was patterned along the suggestion of Professor Amupitan, the legislature limited the exception (special treatment) to only criminal cases, thereby compounding the criteria for determining the competence of a child witness in civil cases.

Also worthy of note in this regard is that there is nothing under the provision of Section 209 (3) to show that the unsworn evidence of a child below the age of fourteen years in civil cases requires corroboration (Roger, 1997). Therefore, the provision of Section 209 (1) of the 2011 Act with regard to a child giving unsworn evidence only applies to criminal cases.

Although it is best that an objection to the competence of a witness be taken at the beginning of the trial so that it can be argued by both parties and determined by the Judge. Previously, it was the law that such objection should be taken while the witness was being examined in chief (Wallaston $v$ Hakewill(1841) 3 Scott N.R. 593); the new trend in practice is to consider it during the final address or even on appeal, as was done in Sambo, Peter and a whole number of other cases decided by superior courts of record of children in Nigeria.

\section{The Preliminary Inquiry of Child Evidence before 2011, Act}

At common law, there are two conditions that determine the competence of a child as a witness. First, he must not be prevented from understanding the questions put to him or from giving rational answers to those questions by reason of tender age. The court does this by putting preliminary questions to the child which may have nothing to do with the matter before the court (Mbele $v$ The State (1990) 4. N.W.L.R. (Pt. 145)). If as a result of this investigation the court comes to the conclusion that the child is unable to understand questions or to answer them rationally, then the child cannot be a witness at all in the case. But if the child passes this test, he is subjected to the second test for the determination of a further question whether he is the opinion of the court is able to understand the nature of an oath. This question is also determined by the court put- 
ting questions to the child, such as: "Do you go to Sunday School?" "Is the Bible a special book?", "Do you understand the importance of God and what will happen to one who tells lies after being sworn on the Holy Bible?" If he fails in this respect he will nevertheless be able to give his evidence but will not take the oath, provided he has passed the first test (Mbele $v$ The State (1990) 4. N.W.L.R. (Pt. 145)). It follows from the principle that, as a general rule, oral evidence shall be on oath or affirmation.

It is important to point out that the test of competence is not mandatory because a trial Judge or Magistrate is not under an obligation to determine the competence of a child unless it is challenged by the other party (Admin, 2017). This was the reasoning of the Supreme Court per Agbaje JSC (as he then was) in the case of Okon v. The State ((1988) ANLR 173 at 186). where he said:

Since all persons are competent to testify, until the competence of a witness to testify is challenged for any of the reasons stated in the section there is in my view no obligation on the court to determine the competence of a witness to testify (Admin, 2017).

It is important that a trial Judge must record the fact that an inquiry was conducted to determine the competence of the child to give rational answers to questions, the sufficiency of intelligence of the child, and whether or not the child understands the duty of speaking the truth. However, a trial judge is not bound to record the specific or actual questions and answers put to the child, and he is only required to state his conclusions. Therefore, failure to record the specific questions and answers put to the child witness will not be fatal to a reasonable opinion and conclusion. In Mbele $v$ The State ((1990) NWLR pt. 145 p484 at 498) appellant contended that the trial judge ought to have recorded the specific questions and answers during the inquiry. Agbaje JSC said:

Once there are clear indications in the record of proceedings that trial Judge carried out the preliminary investigation envisaged by sections 154 and 182 of the Evidence Act before taking the evidence of a child or an infant, that in my view, would mean, at least prima facie, that the said inquiry was carried out even though the actual questions and answers in the course of the investigation are not recorded. It will then be up to counsel for the appellant to rebut this prima facie opinion by showing either there was no investigation at all or that what the trial judge called an investigation.

In the case of Mbele $v$ The State ((1990) (Part 145) 4 NWLR 484-488). The Supreme Court stated the two investigations to be conducted by a court faced with the testimony of a child witness, namely:

1) Whether the child is possessed of sufficient intelligence to be able to understand questions put to him rationally to justify the reception of his evidence; that is, does he understand the duty of speaking the truth? The court does this by putting preliminary questions to the child which may have nothing to do with the matter before the court. If the answer to the first in- 
vestigation is in the negative, then the child cannot be a witness at all in the case. If the answer is in the affirmative then,

2) Whether the child understands the nature of an oath. This second investigation is also determined by the putting of questions to the child as to the nature of an oath such as asking him about God and what will happen to one who tells lies after being sworn, etc. If he fails in this respect, he will nevertheless be able to give evidence, but will not be sworn.

The Supreme Court's decision in the above case was in line with the former Section 183(1) now Section 209(1) of the Evidence Act. This section provides:

In any proceedings in which a child who has not attained the age of fourteen years is tendered as a witness, such a child shall not be sworn and shall give evidence otherwise than on oath affirmation, if in the opinion of the court, he is possessed of sufficient intelligence to justify the reception of the evidence, and understands the duty of speaking the truth (Scharticle.com, 2018).

Commentators on Phipson appear to be skeptical about the efficacy of such investigation as they argue that:

"The conduct of an inquiry by the Judge as to whether a child should be sworn or not may well present problems today" (Phipson, 1983)

Cross and Willins are opposed to the belief in divine sanctions as the basis of a child's competency to testify on oath. Rather, they suggest that what a Judge should consider, is whether the child appreciates the solemnity of the occasion. They exhorted thus:

It used to be said that the Judge had to be satisfied that the proposed witness appreciated the nature and consequences of an oath, and the context made it plain that the court had the divine sanction in mind. The Court of Appeal had recently adopted a more secular approach. The important thing is for the Judge to be satisfied that the child appreciates the solemnity of the occasion and is sufficiently responsible to understand that the taking of an oath involves an obligation, to tell the truth over and over the ordinary duty of doing so. It is unnecessary for the child to believe in anything in the nature of a divine sanction for the majority of the adult population probably does not believe in it (Cross and Wilins, 1981).

On our part, we are in total agreement with the view expressed by Cross and Willins, which agreed with the biblical injunction which states:

Thou shalt not forswear thyself, but shalt perform unto the Lord thine oaths (Matthew 5:37 KJV biblehub.com). But I say unto you, swear not at all; neither by heaven, for it is God's throne Nor by the earth; for it is His footstool: neither by Jerusalem, for it is the city of the great King (Matthew 5:33 KJV biblehub.com). Neither shalt thou swears by thy head, because thou canst not make one hair white or black. But let your communication be, Yea, yea; nay, nay: for 
whatsoever is more than this cometh of evil (Matthew 5:37 KJV: bibblehub.com).

\section{Reform to the Child Witness in England and Wales}

In 1988, England and Wales enacted a new set of laws regarding child witnesses in criminal trials (U. K. Criminal Justice Act, 1988 amendments). The 1988 reforms eliminated the need for corroboration in order to secure a conviction on the unsworn testimony of a child. The reforms also changed the competency inquiry, eliminating the requirement that a child demonstrates an understanding of the "oath," the "truth" or a "promise" to tell the truth. Section 33A of the Criminal Justice Act 1988 provides:

1) A child's evidence in criminal proceedings shall be given unsworn

2) A deposition of a child's unsworn evidence may be taken for the purpose of criminal proceedings as if that evidence had been given on oath.

2a) A child's evidence shall be received unless it appears to the court that the child is incapable of giving intelligible testimony (http://www.legislation.gov.uk).

3) In this law, a "child" means a person less than fourteen years of age.

Thus, in D.P.P. $v$ M. (1997) 2 All E.R. 755) the respondent was convicted of indecently assaulting a four-year-old girl based on the child's unsworn testimony. The respondent appealed, arguing that by reason of her age the child was too young to testify. The English Divisional Court held that it was not open to the Judge to exclude the evidence of the child based on her age alone (per Lord Justice Phillips) The court further stated:

The words of (the new provision) are mandatory. Care must always be taken where a question is raised as to whether a young child is capable of giving intelligible testimony. But where the child is so capable the court does not enjoy some wider discretion to refuse to permit the child's evidence to be given. A child will be capable of giving intelligible testimony if he or she is able to understand questions and to answer them in a manner which is coherent and comprehensible.

In D.P.P. v. G (1998) Q.B. 919) the trial court allowed two young children aged six and eight respectively to give evidence-in-chief and refused to hear testimony from a proposed defence expert that the children were incompetent to testify. The Divisional Court held that the trial court was right to refuse to hear the expert evidence, as the competency inquiry is a simple test well within the capacity of a Judge or Magistrate. The statutory requirement for "intelligible testimony" from the child was held by Lord Justice Phillips to be evidence that is capable of being understood.

In 1999, England and Wales further reformed the law governing child witness competency inquiries in criminal proceedings. The Youth Justice and Criminal Evidence Act 1999 (Stephen, 2015) now provides that children under 14 will testify unsworn (Section 55 (2) (9) and that unsworn evidence should not be given any less weight than sworn testimony: “A deposition of unsworn evidence ... 
maybe taken for the purposes of criminal proceedings as if that evidence had been given on oath" (Section 56 (3)). Section 53 of the same Act states that the sole test for determining the competence of a child to testify is whether the child is "able to understand questions put to him as a witness, and give answers to them which can be understood" Section 53 (3)) (Youth Justice and Criminal Evidence Act 1999 (U.K.) 1999, c 23, s 53(3))

Also, in the case of $R v$. MacPherson, (1997 2 All E.R. 749 at 753) the English Court of Appeal held that once the issue of competence is raised, there is an onus on the party calling the witness, usually the prosecution, to establish that the child is competent to answer questions. However, the trial judge was permitted to satisfy himself that a girl, aged about five years at the time of trial, was competent to testify by viewing the video-record of an investigative interview and engaging the child in a "general conversation... in the form of questions and answers of a most general nature" (Other jurisdictions have legislation very similar to that of England regarding child witness competency assessment). There is no requirement for the Judge to ask the child questions about the difference between truth and falsehood.

\section{Agenda for Reform in Nigeria}

The developed jurisprudence that a child's unsworn evidence may be taken for the purpose of criminal proceedings as if that evidence had been given on oath does not find a place in the Nigerian statutes since a child's competency to testify in our courts today still depends on competency rules inherited from the common law, namely, whether the child has sufficient intelligence to be able to understand questions put to him and whether in the opinion of the court he is able to understand the nature of an oath. Moreover, Section 209 (3) of the Evidence Act still ties down unsworn evidence of a child to corroboration by some other material evidence in support of such testimony before the Accused could be convicted. There is, therefore, an urgent need for the National Assembly to step in and amend Sections 175, 205, 208 and 209 of Evidence Act, 2011 (as amended) in the light of recent law reforms that have taken place in England and Wales as stated above.

In the alternative, we maintain that a separate law relating to children's competency rules be enacted. This is to be known as "The Youth Justice and Criminal Evidence Act" similar to the 1999 England and Wales Youth Justice and Criminal Evidence Act, with some clear provisions that:

1) Child evidence in criminal proceedings shall be given unsworn.

2) A deposition of a child's unsworn evidence may be taken for the purpose of criminal proceedings as if that evidence had been given on oath (Criminal Justice Act 1988, legislation.gov.uk).

3) Evidence of a child less than 14 years of age if received by the Court, shall have effect as if it were taken under Oath.

3) A person under fourteen years of age is presumed to have the capacity to testify. 
4) The evidence of proposed witness under fourteen years of age shall be received if he is able to understand and respond to questions without corroboration.

It is the humble belief of the writers that if our Evidence Act is amended or a separate law relating to child competency rules is enacted in line with the recent law reforms that have taken place in England and Wales put forward in this paper, this will have the advantage of increasing the number of young children eligible to testify in criminal trials in our courts particularly where children are victims or the only eyewitness to the crime.

\section{Conclusion}

In this paper, we have made efforts to show while every person is a competent witness, not every person is a compellable witness. This paper further finds that once a person is a compellable witness afortiori, such a person is presumed a competent witness, because one cannot be compellable if one is first and foremost not competent though one can be competent without being compellable. For instance, children occupy a special position; the law of evidence has specified cases where children are competent, but not compellable or where they are both competent and compellable. This paper also reveals that the competency of a child to give evidence is determined by a test of intellect. This is so because, in a Criminal trial a child will be competent to testify provided he or she can understand the question he is asked and can give understandable answers to them. But in civil trials, a child will be component if he or she satisfies the test for taking an oath or the test as contained under the children's and Young Persons' Act (Section 96 of the CYPA, Cap. C 24 LFN, 2004) for giving unsworn evidence and Section 209 (3) of the Evidence Act, 2011. The article further establishes the fact that the new Evidence Act, 2011 has brought about some positive changes such as abolition of oaths test before a child can testify in court and permit a child who is fourteen years old to give sworn evidence. These improvements are commendable but they have further created the problem of competence and compellability of children's testimony by providing that all other children below fourteen years of age can only give unsworn evidence which unsworn evidence cannot be acted upon by the court unless it is corroborated, and no person can be convicted upon uncorroborated and unsworn evidence of a child.

The study finally finds that the controversial question on the definition of who is a child or a person of tender years in Nigeria has not been resolved under the new Evidence Act. The authors' view in this paper is that until the National Assembly or the Law Reform Commission amends our Evidence Act to provide for the definition of who is a child, our courts will continue to give different interpretations as to who a child is for the purpose of children witness or testimony in our courts particularly on criminal trials.

\section{Conflicts of Interest}

The authors declare no conflicts of interest regarding the publication of this paper. 


\section{References}

Admin (2017). Corroboration of Evidence of Children: The New Tests. https://www.google.com/search?rlz=1C1CHBD_enNG829NG829\&q=Admin( 2017).Corroboration+of+Evidence+of+Children:+The+New+Tests.\&tbm=isc

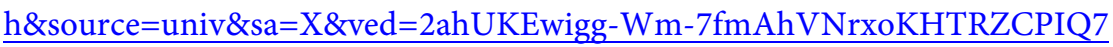
Al6BAgKECQ\&biw $=1280 \&$ bih $=657$

Amusa, K. O. (2014). Fact and Fiction about Child's Evidence in Nigeria. Journal of Humanities and Social Science, 19, 49-53.

https://doi.org/10.9790/0837-19234953

Cross and Wilins (1981). An Introduction to Evidence (5th Edition). London: Butterworths.

Garner, B. (2001). Black's Law Dictionary (8th Edition, p. 254). St. Paul, MN: West Group.

Hornby, A. (2004). Oxford Advanced Dictionary (6th Edition, p. 1072). Oxford: Oxford University Press.

Iguh, N. (2011). An Examination of the Child Rights Protection and Corporal Punishment in Nigeria. Nnamdi Azikiwe University Journal of International law and Jurisprudence.

Onyekachi, D. (2016). Oaths and Affirmations Legal. https://legalemperors.blogspot.com/2016/01/oaths-and-affirmations_11.html

Phipson (1983). The Principle of the Law of Evidence (13th Edition). Scotland: Sweet \& Maxwell.

Roger, S. (1997). The Norton History of the Human Science.

Stephen (2015). Youth Justice: Past, Present and Future. British Journal of Community Justice, 13, 99.

Thomson, D. (1958). Reliability and Credibility of Children as Witnesses. 


\section{Appendix}

\section{Statutes}

Constitution of the Federal Republic of Nigeria, 1999 (as amended)

Section 77(2) and 117(2) of the 1999 Constitution of Nigeria (as amended).

Evidence Act, 2011, Cap. 112 Laws of the Federation of Nigeria, 2004.

Administration of Criminal Justice Act, 2015

Criminal Procedure Act of Nigeria

Children and Young Persons Act, Cap C 24. LFN 2004.

Child's Right Act, Cap C50 LFN, 2004

Convention on the Rights of a Child, 1989

U. K. Criminal Justice Act, 1988 amendments.

The U.K, Criminal Justice Act of 1988 .

Criminal Justice Act, 1991 (U.K)(Amendment)

Criminal Justice Act 1988 by the Criminal Justice and Public Order Act 1994 (U.K) 1994.

Youth Justice and Criminal Evidence Act 1999 (U.K.) 1999, c 23.

Youth Justice and Criminal Evidence Act 1999 (U.K.) 1999.

Cases

1) Barlett v Smith (1842) 12 LJ Ex 287.

2) D.P.P. v M., (1997) 2 All E. R. 755

3) D.P.P. v. G, (1998) Q.B. 919

4) Egbe v. Adefarasin (1985) 1 NWLR pt. 3, 519

5) Ex P Fernandez (1861) 10 CBNS 3

6) Hoskyn v Commissioner of Police for Metropolis (1979) A.C. 474

7) Mbele v The State (1990) 4. N.W.L.R. (Pt. 145) p. 484

8) Ogunsi v The State (1994) 1N.W.L.R. (Pt. 322)10

9) Okoye v The State (1972) 1 All NLR p.500

10) Okon v The State (1998) 1 N.S.C.C. p. 157

11) Onagoruwa v. IGP (1991) 5 NWLR pt 193, 593

12) Okon v The State (1988) 1 N.W.L.R. (Pt. 69) p. 172

13) Onyegbu v The State (1995) 4 N.W.L.R. (Pt. 391) 510

14) Okoyomyo v. The State (1973) NMLR 292

15) R v. Holmes (1861) 175 ER 1286

16) R v Yaccob (1981) Crim L 508

17) R v. MacPherson (1997) 2 All E.R 749 at 753

18) State v Njokwa Obia Vol. 4 ECS LR p.67

19) Solola v State (2005) ALL FWLR (Pt. 269) 1751 S.C

20) Sambo v The State (1993) NWLR (pt. 300) 399

21) Wheeler v United States, 159 US. 523, 525 (1895)

22) Wollaston v Hakewill (1841) 3 Scott N.R. 593 